\title{
Contemporaneous Household Economic Well-being Response to Preschool Children Health Status in Cameroon
}

\author{
Francis Menjo Baye ${ }^{18}$
}

\begin{abstract}
:
This paper estimates the contemporaneous response of household economic well-being to child health status and examines gender disparities in the response process, while controlling for other correlates. The paper uses the 2001 Cameroon household consumption survey and a range of survey-based regressions to generate results. Child health (weight-given age) correlates positively and significantly with household economic well-being, surrogated by log of household total expenditures per adult. This suggests evidence of spill-over effects of child health on household production. The effect of child health on well-being in households headed by women is more than that of their male counterparts. This indicates that with better child health, female heads are likely to exploit the resulting extra-time, budgetary savings and peace of mind at work to increase household well-being more effectively than their male counterparts. These results have implications for public interventions that promote child-day-care/pre-nursery school centres as an important enabler for women to use the extra-time at their disposal to participate additionally in labour market/training opportunities. Investing in reproductive health, especially child health, given the right conditions, can engender income growth, reduce poverty and initiate the process of accumulation of human capabilities.
\end{abstract}

Keywords: Child health, Economic well-being, Household survey data, Cameroon

\subsection{Introduction}

Improving access to and quality of general healthcare, and in particular reproductive health ${ }^{\mathbf{1}}$ is an important component of economic growth and poverty reduction because it shapes human capital and future livelihood opportunities. Early stages of human capital development hinge on child nutrition and health. Poor health during childhood consumes parental resources, time and concentration, and can affect growth potential, capacity to learn, future standards of living and the risk of morbidity and mortality in later years of life. Thus an important mechanism by which poor child health can have a contemporaneous impact on welfare of the household is a result of the increase demand for childcare contributing to lower productivity and labour supply of the parents and other working age members of the household who have to care for the children or expend limited income on their care.

The economic benefits from improved child health come, in part, from reduced infant and child mortality and from reduced costs of healthcare for infants and children. These economic benefits are dominated by productivity gains from improved child health, which releases extratime at the disposal of household members who participate in the labour market and from increased schooling and cognitive ability attributable to health in early childhood. According to empirical studies, better child health improves the timing of school entry, the number of years completed, the learning that takes place per year of schooling and the actual achievements in school, which are commonly shown to lead to increased lifetime earnings (Grantham-McGregor et al., 1999; Filmer and Pritchett 1999; Berhman and Rosenzweig, 2004).

In this regard, children's health has been a major focus of the human capital production function literature in development economics, where production functions have been estimated for child height given age, weight given age, weight given height, birth weight, gestation age and diarrhoeal incidence (see for example, Rosenzweig and Schultz, 1983; Strauss, 1990; Strauss and

\footnotetext{
${ }^{18}$ Faculty of Economics and Management, University of Yaoundé II, Cameroon

P.O. Box 1365 Yaoundé. e-mail bayemenjo@yahoo.com. This paper is inspired by research financially and technically supported by Hewlett Foundation and African Economic Research Consortium (AERC), respectively.
} 
Thomas 1998; Haughton and Haughton, 1997; Dow, 1999; Handa, 1999; Mwabu, 2009; Baye and Fambon, 2009).

Health has long been accepted as an important determinant of human capital along with education and hence factor productivity (Wilhelmson and Gerdtham, 2006). Health provides utility not only directly but also indirectly since it is a key input into many production processes (Grossman, 1972). Health is therefore both a consumption good and an investment good, and differs from other human capital in that it determines the total amount of healthy time available, whereas educational attainment affects the productivity of the time spent on market or nonmarket activities.

Two aspects of the effect of health on productivity have been considered in the endogenous growth literature (Grossman, 1972; Wilhelmson and Gerdtham, 2006): (1) the direct effect of health on the production process - better child and maternal health can increase productivity by reducing inability to work, disability and sick days; and (2) the spill-over effects on labour market participation - better child and mother health can result in extra-time that was previously used for care, at the disposal of household members and friends who may now participate additionally in labour market and training opportunities. Better child and mother health can also lead to savings on medical expenses that can be redeployed for education, food and/or other investments, which may lead to improvements in future labour productivity, growth/household well-being and poverty reduction.

In much of the healthcare demand literature, attempts at establishing linkages between health consumption and health production is increasingly being addressed (see, Gertler and Van de Gaag, 1990; Dow et al., 1999; Mwabu, 2009). Baye and Fambon (2009) establish a link between reproductive healthcare inputs (e.g., parental literacy) with child health production in Cameroon using an anthropometric indicator as a measure of reproductive health. This paper studies the relationship between child health, income growth and poverty reduction. Moreover, if foetal or infant health is retarded, present and future capabilities are similarly affected.

The main objective of this paper is to establish a contemporaneous link between child health (captured by weight - given age) and household economic growth (captured by log of total expenditures per adult). The specific objectives are: (1) to examine effects of child health on household economic well-being, while controlling for other covariates; (2) to examine gender differences in economic well-being response to child health status; and (3) to suggest policy orientations on the basis of the findings. These objectives are guided by the main claim that child health engenders spill-over effects on household economic well-being in Cameroon.

Section 2 of this paper reviews historical and microeconomic studies that attempt to link health to economic growth that have been undertaken elsewhere in the world. Section 3 dwells on the theoretical framework and methodology. Section 4 presents the household survey and description of the variables. Empirical results are presented in Section 5 and Section 6 submits conclusions and policy orientations.

\subsection{Literature Review}

Most of current literature that attempts to create a link between health and economic growth is macroeconomic driven. Yet studies that link health to household economic growth in the context of poverty alleviation should, at least, include microeconomic considerations. Microeconomic studies generally focus on the links between human resources (such as education) and labour market outcomes using individual and household data. Macroeconomic studies assess the effect of health on national income in comparisons between countries or regions (Ruger et al., 2001).

Historical and macroeconomic studies show substantial effects for nutrition and health on income levels in advanced countries and/or on rates of growth in developing countries (MayerFoulkes, 2005). Fogel's Nobel Prize winning work based on analysis of historical data on weight, stature and mortality highlighted the extent of long-term changes in nutrition and health and their impact for long-term economic growth (see, Fogel 1991, 1994a, 1994b, 2002; Fogel and Wimmer, 1992). In the same line, Knowles and Owen (1995) using cross-sectional international data showed a strong and robust relationship between health capital and per capita 
income, and indicated that the effect on income from human capital is greater for health capital than for educational human capital. Further historical evidence of the importance of health for economic growth is provided by Arora (2001), who finds that in the co-integrated relation between health and income, innovations in health lead to economic growth, and not vice versa.

A series of macroeconomic cross-country studies mostly found evidence for a significant impact of life expectancy on economic growth (Barro 1991; Barro and Lee 1994; Barro and Sala-i-Martin 1995; Sachs and Warner 1995; Easterly and Levine 1997; Gallup and Sachs 2000; Sachs and Warner 1997). Bhargava (2001) finds that adult survival rates lead to growth in lowincome countries. This is consistent with a study by Arcand (2001) on the role of nutrition on growth. In a related literature review by Wilhelmson and Gerdtham (2006) of studies using panel data to link health and economic growth: Gupta and Mitra (2004) use infant mortality in an Indian setting as a proxy for health; Ranis et al. (2000) and Bloom et al. (2004) use life expectancy, whereas Jamison et al. (2003) employ adult survival rate for males over 15 years of age; and Blackburn and Cipriani (1998) use infant mortality as a proxy for health. These studies indicate that health is likely to impact on economic growth.

With evidence from within country cross-sectional household data, it is now well established that nutrition and health contribute to labour productivity (e.g. Schultz, 1992, 1997, 1999; Thomas, Schoeni and Strauss, 1997; Strauss and Thomas, 1998). Stature is known to be determined early in life and is a predictor of life-long health and longevity (Schürch and Scrimshaw, 1987; Steckel, 1995). However, the magnitudes found for the effects of health on productivity in these studies are smaller than the magnitudes found in historical and macroeconomic studies. Yet such results remain important for poor households in the context of poverty alleviation and the need to encourage labour intensive systems of production.

Thus, the link between child health and economic growth - established at the macro level - needs to be investigated at the household level in a developing country setting to better appreciate poverty implications, the idea being that households with healthier children will also be the more productive households, at least, in the shorter term. In this direction, there appears to be no study which explicitly establishes a link between child health and household economic well-being. This study attempts to fill this gap.

\subsection{Theoretical framework and methodology}

\subsection{Theoretical framework}

This paper is envisaged within a framework in which household utility encompasses child health. In this context, child health and general health provides utility not only directly but also indirectly, since it is a key input into many household production processes. Family health, especially child health is an important component of economic growth and poverty reduction because it shapes both present and future human capital, as well as livelihood prospects. Thus good health at childhood, as argued, does not only affect the physical growth potential, risk of morbidity and mortality in later years of life; but also releases potential household savings on medical expenditures and extra-time to adult household members to take more advantage of labour market opportunities, as well as the child's capacity to learn and prospects for better future standards of living. In this regard, children's health can be considered as an important input in the well-being production function of the household - registering mainly indirect effects on household income via the extra-time.

\subsection{Methodology}

Child health is, therefore, assumed to be a significant input that correlates with household economic well-being. Since household economic well-being (EWB) and child health $(\mathrm{CH})$ are jointly determined and each has a ceteris paribus behavioural interpretation, their causal links can be depicted by the following structural equations (see, Wooldrige, 2002). 


$$
\begin{gathered}
E W B=v_{1} \partial_{e w b}+\varphi_{1} C H+\varepsilon_{1} \\
(1) \\
C H=v_{2} \partial_{c h}+\varphi_{2} E W B+\varepsilon_{2}
\end{gathered}
$$

(2)

where, EWB is economic well-being surrogated by adult per capita household expenditure - the endogenous explanatory variable in the child health production function; $\mathrm{CH}$ is child health - the endogenous explanatory variable in the EWB production function - captured by weight-for-age z-scores; $v_{1}$ is a vector of exogenous variables that determine household economic well-being; $v_{2}$ is a vector of exogenous variables that determine child health $(\mathrm{CH})$; and $\partial, \varphi$, are parameters to be estimated, and $\varepsilon_{1}$ and $\varepsilon_{2}$ are the two structural error terms because they appear in the structural equations. Given that $\mathrm{CH}$ is determined simultaneously with $\mathrm{EWB}$, it is correlated with $\varepsilon_{1}$, which leads to bias and inconsistency in OLS estimates. By the same token, EWB is correlated with $\varepsilon_{2}$. Since the interest here is to estimate Equation 1, if the right-hand side of Equation 1 is plugged in for EWB in Equation 2, one gets:

$$
C H=v_{2} \partial_{c h}+\varphi_{2}\left(v_{1} \partial_{e w b}+\varphi_{1} C H+\varepsilon_{1}\right)+\varepsilon_{2}
$$

To solve for $\mathrm{CH}$, the assumption must be made that: $\varphi_{2} \varphi_{1} \neq 1$. Whether this assumption is restrictive or not is an empirical issue. Equation 3 simplifies to Equations 4 and 5:

$$
\left(1-\varphi_{2} \varphi_{1}\right) C H=\varphi_{2} v_{1} \partial_{e w b}+v_{2} \partial_{c h}+\varphi_{2} \varepsilon_{1}+\varepsilon_{2}
$$

$$
C H=v_{1} z_{e w b}+v_{2} z_{c h}+\varepsilon_{3}
$$

where, $\quad\left(z_{\text {ewb }}=\left(\varphi_{2} \partial_{\text {ewb }}\right) /\left(1-\varphi_{2} \varphi_{1}\right)\right.$;

$$
\left(z_{c h}=\left(\partial_{c h}\right) /\left(1-\varphi_{2} \varphi_{1}\right)\right.
$$

and $\left(\varepsilon_{3}=\left(\varphi_{2} \varepsilon_{1}+\varepsilon_{2}\right) /\left(1-\varphi_{2} \varphi_{1}\right)\right.$. Equation 5 , which expresses $\mathrm{CH}$ in terms of the vector of exogenous variables $z_{\text {ewb }}$ and $z_{c h}$, and the error terms, is the reduced form equation for $\mathrm{CH}$. The vector of parameters $v_{1}$ and $v_{2}$ are reduced form parameters - they are nonlinear functions of the structural parameters in Equations 1 and 2. The reduced form error, $\varepsilon_{3}$, is a linear function of the structural error terms, $\varepsilon_{1}$ and $\varepsilon_{2}$. Since $\varepsilon_{l}$ and $\varepsilon_{2}$ are each uncorrelated with $v_{l}$ and $v_{2}, \varepsilon_{3}$ is also uncorrelated with $v_{l}$ and $v_{2}$. Thus, the vectors of parameters $z_{e w b}$ and $z_{c h}$ can be consistently estimated by the OLS - this is input in 2SLS estimation.

Measurement Issues

The attention of this paper is on the effect of child health on economic well-being. Estimation of the parameters of the economic well-being production function requires knowledge of inputs into the process and, since inputs and outputs are jointly determined, causality might run in the other direction (reverse causality). Moreover, many studies have shown that economic development is a key determinant of health outcomes (Preston, 1975; Case et al., 2005). A conventional method to reduce the problem of endogeneity is to use the instrumental variable (IV) method.

In Equation (1), child health is endogenous in the income generating function because it is a product of reproductive health technologies and is hypothesized to complement with relevant determinants of the well-being production function that are unobserved. In this context, potential instruments for child health are needed in order to consistently estimate effects of child health on economic well-being. The instruments for child health are those factors that affect the demand for child health without directly influencing economic well-being. These institutional and supply-side factors may include time and distance to accessing some basic utilities (such as health centre, school, road or waste disposal), location and child characteristics such as gender and age in months.

In addition, heterogeneity of economic well-being due to non-linear interaction of child health with unobservable or omitted variables could bias the estimated structural coefficients. 
We appeal to the control function approach to address this potential issue (see, Garen, 1984; Wooldridge, 1997; Mwabu, 2009). Thus, to account for the potential endogeneity and heterogeneity of responses of unobservables that are complementary with child health, Equation 1 can be augmented to Equation 6, which is the control function model.

$$
E W B=\beta_{0}+v_{1} \partial+\varphi_{1} C H+\beta_{1} \hat{\varepsilon}_{3}+\theta\left(\hat{\varepsilon}_{3} * C H\right)+u
$$

where, $\hat{\varepsilon}_{3}$ is fitted residual of child health $(\mathrm{CH})$, derived from the reduced form model of child health (Equation 5); $\left(\hat{\varepsilon}_{3} * \mathrm{CH}\right)$ is interaction of the fitted child health residual with the actual value of the child health variable; is the error term; and , and are parameters to be estimated.

As noted in Wooldridge (1997), the IV estimates of Equation 6 are unbiased and consistent only when: (a) the expected value of the interaction between child health and its residual $\left(\hat{\varepsilon}_{3} * \mathrm{CH}\right)$ is zero or the interaction between child health and its fitted residual is linear and (b) there is no sample selection problem. However, if the correlation is non-linear, then the control function approach is required and the inclusion of the interaction term, $\left(\hat{\varepsilon}_{3} * \mathrm{CH}\right)$, in Equation 6 purges the estimated coefficients of the effects of unobservable variables (see, Card, 2001; Mwabu, 2009). When the two control function variables $\left(\hat{\varepsilon}_{3}\right.$ and $\left.\left(\hat{\varepsilon}_{3} * \mathrm{CH}\right)\right)$ are generated, then estimation of Equation 6 will purge the structural estimates of the parameters of EWB of potential simultaneity bias and unobserved heterogeneity.

However, the estimates of Equation 6 may not be applicable to all preschool aged children because children whose weights or ages were not registered are not reflected in Equation 6. Thus failing to consider an approach that reflects the entire sample of children means that parameter estimates may suffer from sample selection bias. To address the sample selection problem, Equation 7 is introduced.

$$
S=1\left(v \delta_{s}+\varepsilon_{4}>0\right) \Leftrightarrow \text { If } C H \text { is unobserved } S \leq 0 \text { and } S=1 \text { if } C H \text { is observed }
$$

where, $\mathrm{S}$ is a dichotomous indicator function for selection of the observations into the sample, $\mathrm{v}$ is a vector of exogenous variables, comprising of $v_{1}$ explanatory variables that belong to the well-being production function (outcome equation) and a vector of variables that instrument for the sample selection indicator, and $\delta$ and $\varepsilon$ are parameters to be estimated and the error term.

One way of proceeding is to apply the Heckman approach (Statacorp., 2001) that jointly estimates the probit for sample selection (Equation 7) and the structural parameters including the predicted residuals and interaction terms (Equation 6) by the maximum likelihood estimation (MLE) procedure to purge the structural estimates of potential simultaneity bias, unobserved heterogeneity and sample selection bias concurrently. The coefficient of the resulting inverse of the Mills ratio, which controls for sample selection bias, is the product of the correlation coefficient between $u$ and $\varepsilon_{4}$, and the standard deviation of $u{ }^{1}$ These sample statistics are generated automatically upon convergence of the log-likelihood function.

The null hypothesis of no significant effect of child health on household income is $\mathrm{H}_{0}$ : $\varphi_{1}=0$. The alternative hypothesis $\varphi_{1}>0$ is presumed to act through increased labour market participation in response to extra-time at the disposal of household members because children are in good health. More generally, better child health increases household income through potential savings that could be realised on health expenditures and indirectly through extra-time that could be redeployed to additional labour market participation opportunities. The key argument here is not that child health directly increases household income, but that better child health elicits extratime, which is strongly correlated with enhanced training and labour market participation possibilities that increase household income. 


\subsection{Data, Child Health Measures and Estimation Procedure}

\subsection{Data Presentation}

This paper uses data extracted from the second Cameroon Household Consumption Survey (CHCS II) collected by the National Institute of Statistics in the period September - December 2001. This survey includes 12000 household and 4516 preschool children of up to 36 months old. The survey was based on the second General Population and Housing Census (GPHS) of April 1987 updated for its age. Two types of sampling designs were undertaken depending on the zone of residence. In the main cities of Yaoundé and Douala, a two-stage sampling frame was adopted. For rural areas, a three-stage random sampling frame was adopted following the sequence city-primary sampling unit-household. Overall, 612 primary sampling units were identified covering the entire country.

The survey questionnaire was formulated in 15 sections, many of which can assist in linking up child health to household economic growth and poverty. Taking into consideration the linkages existing between the different sections of the questionnaire, files containing information on individuals and households characteristics were used. At the level of individuals, information compiled includes: demographic characteristics; and education of household heads, as well as anthropometric characteristics of children aged 0-36 months. At the household level, among other things, the survey gathered information on access to basic infrastructures, access to social services, land ownership, and total expenditures.

To design the relevant analytic sample, the file with individual characteristics was merged horizontally with the files containing anthropometrics of children aged 0-36 months, access to land and property, and access to basic social infrastructures taking into consideration the identifiers contained in the different files. The unit of analysis is the child and the endogenous explanatory variable of interest is weight-for-age z-score $(\mathrm{CH})$ proxy for child health/nutritional status. The dependent variable used for the income generating function is log of household total expenditure per adult in CFA francs. The empirical analysis is informed by the variables described in Table 2.

\subsection{Measures of Child Health/Nutrition}

Anthropometric indices are generally used to capture child health/nutritional status in the health literature (see, Waterlow et al., 1977; WHO Working Group 1986; Gorstein et al. 1994). Height (given age) depicts long-term nutritional status since it reflects both current and past nutritional intake. Since weight can change in a relatively short period of time as a consequence of changes in nutritional intake and/or health status, weight-for-height and Weight-for-age are considered measures of short-term nutritional status. Weight-for-height tends to have an advantage over the other two measures since it does not depend on the availability of correct reports on child age in months. However, weight-for-age can be seen as a combination of the other two indices because unlike weight given height it does not distinguish between small but well fed children and tall but thin ones. Weight (given age) reflects signs of temporary lack of food or recent or current episodes of illness. ${ }^{1}$

\subsection{Estimation Procedure}

Use is made of econometric procedures that correct for potential endogeniety, sample selection biased and unobserved heterogeneity simultaneously. In order to control for sample design used for data collection, survey-based regression models in STATA are used. Survey regressions take care of three important sample characteristics: sampling weights, clustering, and stratification. Failure to include sampling weights gives estimates that are not representative of the underlying population and affect standard errors of the estimates. In addition, because of the sampling design, observations in a cluster are strictly not independent ${ }^{1}$ and using the standard regression methods without correcting for intra-cluster correlation will give small standard errors which 
invalidate significance tests. Accounting for clustering is therefore necessary to adjust the standard errors for both survey design effects and cluster level effects.

\subsection{Empirical Results}

\subsection{Weighted Descriptive Statistics}

Table 1 provides weighted summary statistics describing the analytic sample population. About 87 per cent of households in our sample are headed by men with only about 13 per cent by women. The average age of household heads is 43 years. On the average, children captured in our sample are aged about 16 months and slightly over 50 per cent of them are boys. Approximately 69 per cent of household heads are literate, against 31 per cent who are nonliterate. In particular, up to 38 per cent are primary school leavers, 27 per cent secondary school leavers and only 5 per cent are university graduates. The average weight-for-age is about $-0.29 \mathrm{z}-$ scores, which is above the weight poverty line of -2 z-scores. Average total land holding per household hosting at least a child 0-36 months old is about 9 acres. The average distance to reach the nearest food market is about $2 \mathrm{~km}$. About 70 per cent of households leave in rural areas. Average annual household expenditure per adult is about 171099 CFA francs (see, Table 1).

Table 1: Descriptive Statistics of variables short-listed for regression analysis

\begin{tabular}{lllll}
\hline Variable & No. of Obs & Population & Mean & Std. Dev. \\
\hline
\end{tabular}

1. Outcome variables

Dependent Variable:

Log of household total annual expenditure per adult

Endogenous Explanatory Variable

\begin{tabular}{|c|c|c|c|}
\hline 4516 & 9713362 & 12.05 & 0.64 \\
\hline 4168 & 8966896 & -0.29 & 3.40 \\
\hline 4516 & 9713362 & 0.31 & 0.46 \\
\hline 4516 & 9713362 & 0.38 & 0.48 \\
\hline 4516 & 9713362 & 0.26 & 0.44 \\
\hline 4516 & 9713362 & 0.05 & 0.21 \\
\hline 4494 & 9658158 & 2.14 & 0.62 \\
\hline 4494 & 9658158 & 4.97 & 2.97 \\
\hline 4516 & 9713362 & 0.22 & 0.41 \\
\hline 4516 & 9713362 & 9.57 & 4.97 \\
\hline 4516 & 9713362 & 116,33 & 144,36 \\
\hline 4516 & 9713362 & 1,28 & 1,34 \\
\hline 4516 & 9713362 & 1,01 & 1,23 \\
\hline 4516 & 9713362 & 0,78 & 0,99 \\
\hline 4516 & 9713362 & 2,32 & 1,32 \\
\hline 4516 & 9713362 & 0,25 & 0,56 \\
\hline
\end{tabular}

Child Health (Weight for Age Z-Score of the 0-36 months old) (CH)

Exogenous explanatory Variables

$\begin{array}{cccc}4516 & 9713362 & 12.05 & 0.64 \\ & & & \\ 4168 & 8966896 & -0.29 & 3.40 \\ & & & \\ 4516 & 9713362 & 0.31 & 0.46 \\ 4516 & 9713362 & 0.38 & 0.48 \\ 4516 & 9713362 & 0.26 & 0.44 \\ 4516 & 9713362 & 0.05 & 0.21 \\ 4494 & 9658158 & 2.14 & 0.62 \\ 4494 & 9658158 & 4.97 & 2.97 \\ 4516 & 9713362 & 0.22 & 0.41 \\ 4516 & 9713362 & 9.57 & 4.97 \\ 4516 & 9713362 & 116,33 & 144,36 \\ 4516 & 9713362 & 1,28 & 1,34 \\ 4516 & 9713362 & 1,01 & 1,23 \\ 4516 & 9713362 & 0,78 & 0,99 \\ 4516 & 9713362 & 2,32 & 1,32 \\ 4516 & 9713362 & 0,25 & 0,56\end{array}$

No level of education by the household head

Primary level education attained by household head

Secondary level education attained by household head

University level education attained by household head

Log of total land area in acres owned by households (logland)

Log of total land area owned by household squared (logland squared)

Formal Sector Employment=1 and 0, otherwise

Household size

Household size squared

$\mathrm{H} / \mathrm{h}$ members in 10-14 Years Age Group

$\mathrm{H} / \mathrm{h}$ members in 15-19 Years Age Group

H/h members in 20-24 Years Age Group

$\mathrm{H} / \mathrm{h}$ members in 25-59 Years Age Group

$\mathrm{H} / \mathrm{h}$ members in $\geq 60$ Years Age Group

2. Instruments for child health and sample selection

Log of distance to nearest food market in meters 
(logdistfoodmkt)

Gender of child: male_child=1 and 0, otherwise

Child age in months (child_age)

Child age squared (child_age squared)

Rural household=1 and 0, otherwise

\section{Controls for unobservable variables}

Predicted child health residual (CH minus its fitted value)

Child health times its residual

\begin{tabular}{lccc}
4516 & 9713362 & 0.51 & 0.50 \\
4394 & 9411977 & 15.78 & 9.94 \\
4394 & 9411977 & 347.68 & 342.24 \\
4516 & 9713362 & 0.70 & 0.46 \\
& & & \\
4025 & 8614302 & 0.089 & 2.692 \\
4025 & 8614302 & 7.149 & 18.538 \\
& & & \\
4516 & 9713362 & 0.866 & 0.340 \\
4516 & 9713362 & 0.134 & 0.340 \\
\hline
\end{tabular}

4. Variables identifying Gender

Male household heads $=1$ and 0 , otherwise

Female household heads $=1$ and 0 , otherwise

4516

Source: Compiled by author from the CHCS II data set.

\subsection{Estimates of the Economic Well-being Production Function}

The expectation here is that if a child is in good health, the household may benefit from potential savings on medical expenditures and extra-time that could be redeployed to additional income earning activities that improve household income and enhance the well-being status of the household. Table 2 presents estimates of the income generating function under different assumptions using child health as the main right-hand-side variable, while controlling for other correlates. Column (1) shows the OLS estimates of the structural parameters, which are clearly not representative of the underlying population. The other columns give survey-based regression models that are representative of the underlying population.

In particular, Column (2) of Table 2 shows survey-based linear regression results that have been cured of potential intra-cluster correlation, but these estimates may still be contaminated by other econometric problems. Column (3) gives survey-based 2SLS estimates of the structural parameters accounting for endogeneity of child health, but not sample selection or unobserved heterogeneity. Column (4a) accounts for endogeniety and sample selection bias, while in addition, Column (4b) checks whether unobserved heterogeneity is a problem.

Child health is positively and significantly associated with the production of household economic well-being, captured by log of total household expenditure per adult. This is preliminary evidence of spill-over effects of child health on household economic well-being. According to the 2SLS estimates (Column 3), child health increases the production of an average household by as much as about 5.2 times the linear regression estimate of 0.009 (Column 2). Control function estimates (Columns $4 \mathrm{a}$ and $4 \mathrm{~b}$ ) yield identical effects of child health on household well-being of 0.051, which is about 1.1 times the 2SLS estimate of 0.047 (Column 3). These results show that using the correct estimation procedure is critical for policy implications. There is no evidence of unobserved heterogeneity since the interaction of child health with its fitted residual fails to be significant (Column $4 \mathrm{~b}$ ). Thus the parsimonious estimates in column 4a are the preferred results for the full sample (Table 2).

Examining the reduced form estimates for child health in Table A in the Appendix, it is apparent that distance to food markets, boy-child, child age and rural residency are each individually significant in inversely affecting the demand for better childcare. Child age registers increasing returns to child health. The parameter estimates of the five identifying child health variables are jointly significant $(\mathrm{p}<0.000)$, according to the Anderson-Rubin F-statistics of 65.99. According to the weak identification tests in the lower panel of Table 2, the Cragg-Donald statistics of 85.47 is much larger than Stock-Yogo weak ID test critical values: $5 \%$ maximal IV relative bias of 18.35 (Column 3 of Table 2), thus rejecting the possibility that the five instruments are weak. 
In addition, diagnostic tests at the bottom of Column 3 of Table 2 show that the Durbin-WuHausman chi-square test rejects exogeneity of child health in the well-being production function. The coefficient of the predicted residual of child health (Column 4a) is statistically significant, confirming that this input into household economic well-being is indeed endogenous, so that inclusion of this residual term in the income generating equation, as is done here, is required for consistent estimation of structural parameters.

Table 2: Economic Well-being Production function under different assumptions - Dependent variable: log of household total expenditures per adult (Robust linearized t-statistics in parentheses, except otherwise specified)

\begin{tabular}{|c|c|c|c|c|c|}
\hline \multirow{3}{*}{$\begin{array}{l}\text { Method of } \\
\text { estimation: }\end{array}$} & \multirow{3}{*}{$\begin{array}{l}\text { Ordinary Least } \\
\text { Squares (OLS) } \\
\text { (1) }\end{array}$} & \multicolumn{4}{|c|}{ Survey-based Regression Models: } \\
\hline & & \multirow[t]{2}{*}{$\begin{array}{l}\text { Linear } \\
\text { Regression (2) }\end{array}$} & \multirow[t]{2}{*}{$\begin{array}{l}\text { IV } \underset{(3)}{\operatorname{2SLS}} \\
\text { (3) }\end{array}$} & \multicolumn{2}{|c|}{$\begin{array}{c}\text { Heckman/control function } \\
\text { approach }\end{array}$} \\
\hline & & & & (4a) & $(4 \mathrm{~b})$ \\
\hline \multirow[t]{2}{*}{ Child health } & $0.008^{* *}$ & $0.009^{* *}$ & $0.047^{* * *}$ & $0.051^{* * *}$ & $0.051^{* * *}$ \\
\hline & $(2.51)$ & $(2.42)$ & $(3.2)$ & (3.54) & (3.55) \\
\hline \multirow[t]{2}{*}{ Primary education } & $0.116^{* * *}$ & $0.078^{* *}$ & $0.074^{*}$ & $0.075^{*}$ & $0.075^{*}$ \\
\hline & (5.18) & $(1.98)$ & $(1.85)$ & (1.89) & (1.89) \\
\hline \multirow{3}{*}{$\begin{array}{l}\text { Secondary } \\
\text { education }\end{array}$} & & & & & \\
\hline & $0.326^{* * *}$ & $0.331^{* * *}$ & $0.314^{* * *}$ & $0.317^{* * *}$ & $0.317^{* * *}$ \\
\hline & $(13.46)$ & $(5.34)$ & $(5.02)$ & $(4.91)$ & $(4.91)$ \\
\hline \multirow{3}{*}{$\begin{array}{l}\text { University } \\
\text { education }\end{array}$} & & & & & \\
\hline & $0.746^{* * *}$ & $0.710^{\text {**** }}$ & $0.656^{* * *}$ & $0.661^{\text {**** }}$ & $0.658^{* * *}$ \\
\hline & (18.62) & $(9.65)$ & (7.68) & (8.17) & (8.2) \\
\hline \multirow[t]{2}{*}{ logland } & $0.095^{* *}$ & $0.300^{* * *}$ & $0.301^{* * *}$ & $0.303^{* * *}$ & $0.305^{* * *}$ \\
\hline & $(2.16)$ & (3.8) & (3.67) & $(3.81)$ & (3.84) \\
\hline \multirow[t]{2}{*}{ logland sqaured } & -0.015 & $-0.058^{* * *}$ & $-0.059^{* * *}$ & $-0.059^{* * *}$ & $-0.060^{* * * *}$ \\
\hline & $(-1.52)$ & $(-3.54)$ & $(-3.44)$ & $(-3.57)$ & $(-3.58)$ \\
\hline \multirow{2}{*}{$\begin{array}{l}\text { Formal sector } \\
\text { employment }\end{array}$} & $0314^{* * * *}$ & $0376^{* * * *}$ & $0215^{* * *}$ & $211^{* * * *}$ & \\
\hline & $\begin{array}{l}0.314 \\
(14.89)\end{array}$ & $\begin{array}{l}0.3<0 \\
(4.88)\end{array}$ & $\begin{array}{l}0.315 \\
(4.67)\end{array}$ & $\begin{array}{c}0.311 \\
(4.67)\end{array}$ & $\begin{array}{r}.312 \\
(4.74)\end{array}$ \\
\hline \multirow[t]{2}{*}{ Household size } & $-0.124^{* * *}$ & $-0.103^{* * *}$ & $-0.103^{* * *}$ & $-0.104^{* * *}$ & $-0.104^{* * * *}$ \\
\hline & $(-16.53)$ & $(-7.53)$ & $(-7.68)$ & $(-7.36)$ & $(-7.33)$ \\
\hline \multirow{3}{*}{$\begin{array}{l}\text { Household size } \\
\text { squared }\end{array}$} & & & & & \\
\hline & $0.002^{* * *}$ & $0.001^{* * *}$ & $0.001^{* * *}$ & $0.001^{* * *}$ & $0.001^{* * *}$ \\
\hline & (8.94) & (2.79) & (2.88) & $(2.67)$ & (2.68) \\
\hline \multirow{3}{*}{$\begin{array}{l}10-14 \text { Years age } \\
\text { group }\end{array}$} & & & & & \\
\hline & 0.003 & 0.018 & 0.026 & 0.026 & 0.025 \\
\hline & $(0.24)$ & (0.89) & $(1.21)$ & $(1.24)$ & (1.21) \\
\hline \multirow{2}{*}{$\begin{array}{l}15-19 \text { Years age } \\
\text { group }\end{array}$} & $0.094^{* * *}$ & $0.087^{* * *}$ & $0.084^{* * *}$ & $0.087^{* * *}$ & $0.087^{* * *}$ \\
\hline & $(8.72)$ & $(4.56)$ & $(4.57)$ & $(4.68)$ & (4.66) \\
\hline \multirow{3}{*}{$\begin{array}{l}20-24 \text { Years age } \\
\text { group }\end{array}$} & & & & & \\
\hline & $0.090^{* * *}$ & $0.063^{* * *}$ & $0.063^{* * *}$ & $0.063^{* * *}$ & $0.063^{* * *}$ \\
\hline & $(7.63)$ & $(2.67)$ & $(2.61)$ & $(2.67)$ & (2.62) \\
\hline \multirow[t]{2}{*}{$\begin{array}{l}25-59 \text { Years age } \\
\text { group }\end{array}$} & $0.106^{* * *}$ & $0.111^{* * *}$ & $0.111^{* * *}$ & $0.113^{* * *}$ & $0.112^{* * *}$ \\
\hline & $(9.25)$ & (4.39) & (4.3) & $(4.46)$ & $(4.46)$ \\
\hline \multirow{3}{*}{$\begin{array}{l}\geq 60 \text { Years age } \\
\text { group }\end{array}$} & & & & & \\
\hline & 0.014 & 0.017 & 0.002 & -0.000 & -0.000 \\
\hline & $(0.74)$ & $(0.52)$ & $(0.06)$ & $(-0.01)$ & $(-0.01)$ \\
\hline
\end{tabular}


Control Function Variables (account for Economic Well-being effects of unobservables in the error term)

Child health

residual

$-0.045^{* * *}$

Child health times

its residual

Inverse of the

mills ratio

Constant

R-squared

F-Stat [df; p-val]

$\rho$ (correlation of

well-being

residual with

sample selection

residual) [Std.

Err.]

$\sigma$ (sigma of well-

being residual)

[Std. Err.]

Weak

identification test:

Cragg-Donald F-

Stat [5\% maximal

IV relative bias]

Durbin-Wu-

Hausman Chi2

test for exogeneity

of the potential

endogenous

variables [df; p-

value]

Uncensored

observations

Number of

clusters [Design

df]

Population
$-0.114^{*}$

$(-1.71)$

$11.965^{* * * *}$

(99.72)

(96.26)

(98.58)

(195.24)

0.3345

0.3297

143.96 [14,

4010; 0.000]

$52.15[14$,

573;

$0.000]$

49.35 [14, 573;

0.000]

$48.76[15$,
85.47 [18.35]

18.144 [1;0.000]

4025

592 [586]

8614302
$-0.045^{* * *}$

$-0.113^{*}$

572; 0.000]

46.01 [16,

571; 0.000]

$-0.218[0.12]$

$-0.216[0.12]$

$0.522[0.02]$

$0.522[0.02]$

Source: Computed by author using CHS II survey data and STATA 9.1.

Notes: (·) implies $t$-ratios. ${ }^{* * *},{ }^{* *}$ and $*$ indicate $1 \%, 5 \%$ and $10 \%$ levels of significance, respectively.

The preferred estimates for the full sample are reproduced in Table 3 together with estimates for the male and female sub-samples. As shown in Table 3, child health is statistically significantly associated with the production of household economic well-being (Columns 1-3). The magnitude of the influence of better child health on production of female headed households is in excess of that of their male counterparts, though significant only at the $10 \%$ level. This indicates that when children are healthy, female heads are likely to exploit the resulting extra-time, budgetary savings and peace of mind at work to increase household economic well-being more effectively than their male counterparts. This result has implications for public policy interventions that can enable women to take additional advantage of labour market/training opportunities. 
Table 3: Economic Well-being Production function by gender of Household Head - Dependent variable: $\log$ of household total expenditures per adult (Robust linearized t-statistics in parentheses, except otherwise specified)

\begin{tabular}{|c|c|c|c|}
\hline Variables & $\begin{array}{l}\text { Method of esti } \\
\text { approach } \\
\text { All (1) }\end{array}$ & $\begin{array}{l}\text { ey-based H } \\
\text { Male (2) }\end{array}$ & $\begin{array}{l}\text { function } \\
\text { Female (3) }\end{array}$ \\
\hline Child health $(\mathrm{CH})$ & $\begin{array}{c}0.051^{* * *} \\
(3.54)\end{array}$ & $\begin{array}{c}0.044^{* * *} \\
(2.66)\end{array}$ & $\begin{array}{l}0.062^{*} \\
(1.85)\end{array}$ \\
\hline Primary education & $\begin{array}{l}0.075^{*} \\
(1.89)\end{array}$ & $\begin{array}{l}0.044 \\
(0.98)\end{array}$ & $\begin{array}{r}0.244^{* * *} \\
(3.26)\end{array}$ \\
\hline Secondary education & $\begin{array}{c}0.317^{* * *} \\
(4.91)\end{array}$ & $\begin{array}{c}0.291^{* * *} \\
(4.46)\end{array}$ & $\begin{array}{r}0.464^{* * *} \\
(4.00)\end{array}$ \\
\hline University education & $\begin{array}{c}0.661^{* * *} \\
(8.17)\end{array}$ & $\begin{array}{c}0.647^{* * *} \\
(7.9)\end{array}$ & $\begin{array}{r}0.996^{* * *} \\
(5.00)\end{array}$ \\
\hline logland & $\begin{array}{c}0.303^{* * *} \\
(3.81)\end{array}$ & $\begin{array}{c}0.250^{* * *} \\
(3.52)\end{array}$ & $\begin{array}{r}0.834^{* * * *} \\
(3.66)\end{array}$ \\
\hline logland squared & $\begin{array}{c}-0.059^{* * *} \\
(-3.57)\end{array}$ & $\begin{array}{c}-0.050^{* * *} \\
(-3.16)\end{array}$ & $\begin{array}{r}-0.150^{* * *} \\
(-3.35)\end{array}$ \\
\hline Formal sector employment & $\begin{array}{c}0.311^{* * *} \\
(4.67)\end{array}$ & $\begin{array}{c}0.323^{* * *} \\
(5.33)\end{array}$ & $\begin{array}{l}0.250^{*} \\
(1.89)\end{array}$ \\
\hline Household size & $\begin{array}{c}-0.104^{* * *} \\
(-7.36)\end{array}$ & $\begin{array}{c}-0.100^{* * * *} \\
(-6.66)\end{array}$ & $\begin{array}{r}-0.122^{* * * *} \\
(-4.82)\end{array}$ \\
\hline Household size squared & $\begin{array}{c}0.001^{* * *} \\
(2.67)\end{array}$ & $\begin{array}{l}0.001^{* * *} \\
(2.55)\end{array}$ & $\begin{array}{l}0.001 \\
(1.48)\end{array}$ \\
\hline 10-14 Years age group & $\begin{array}{l}0.026 \\
(1.24)\end{array}$ & $\begin{array}{l}0.028 \\
(1.24)\end{array}$ & $\begin{array}{r}0.008 \\
(0.18)\end{array}$ \\
\hline 15-19 Years age group & $\begin{array}{c}0.087^{* * *} \\
(4.68)\end{array}$ & $\begin{array}{c}0.077^{* * * *} \\
(3.82)\end{array}$ & $\begin{array}{r}0.117^{* * * *} \\
(3.44)\end{array}$ \\
\hline 20-24 Years age group & $\begin{array}{c}0.063^{* * *} \\
(2.67)\end{array}$ & $\begin{array}{c}0.066^{* * *} \\
(2.93)\end{array}$ & $\begin{array}{r}0.076^{* *} \\
(1.99)\end{array}$ \\
\hline 25-59 Years age group & $\begin{array}{l}0.113^{* * *} \\
(4.46)\end{array}$ & $\begin{array}{l}0.104^{* * *} \\
(3.69)\end{array}$ & $\begin{array}{c}0.181^{* * * *} \\
(4.19)\end{array}$ \\
\hline$\geq 60$ Years age group & $\begin{array}{l}-0.000 \\
(-0.01)\end{array}$ & $\begin{array}{l}-0.007 \\
(-0.2)\end{array}$ & $\begin{array}{l}0.137^{*} \\
(1.86)\end{array}$ \\
\hline
\end{tabular}

Control Function Variables (Account for Economic Well-being effects of unobservables in the error term)

Child health residual

Inverse of the mills ratio

Constant

F-Stat [df ; p-value]

$\rho$ (correlation of well-being

residual with sample

selection residual) [Std.

Err.]

$$
-0.045^{* * *}
$$

$$
(-3.07)
$$$$
-0.114^{*}
$$$$
(-1.71)
$$$$
11.965^{* * *}
$$$$
\text { (99.72) }
$$$$
48.76 \text { [15, 572; }
$$$$
0.000]
$$$$
-0.036^{* *}
$$$$
(-2.14)
$$$$
-0.121^{* *}
$$$$
\text { (-2.28) }
$$$$
12.033^{* * *}
$$$$
\text { (108.13) }
$$$$
44.64 \text { [15, 558; }
$$$$
0.000]
$$$$
-0.068^{*}
$$

$11.130^{* * *}$

16.16 [15, 319;

0.000]

$-0.218$

[0.12]

$-0.234$

[0.10] 


\begin{tabular}{lccc}
$\sigma$ (sigma of well-being & 0.522 & 0.520 & 0.518 \\
$\begin{array}{l}\text { residual) } \\
\text { [Std. Err.] }\end{array}$ & {$[0.02]$} & {$[0.02]$} & {$[0.03]$} \\
$\begin{array}{l}\text { Uncensored observations } \\
\begin{array}{l}\text { Number of clusters [Design } \\
\text { df] }\end{array}\end{array}$ & 5925 & 3374 & 651 \\
Population & 8614302 & $578[572]$ & $339[333]$ \\
\hline
\end{tabular}

Source: Computed by author using CHS II survey data and STATA 9.1.

Notes: $(\cdot)$ implies $t$-ratios. $* * *, * *$ and $*$ indicate $1 \%, 5 \%$ and $10 \%$ levels of significance, respectively. The results for the full sample in Columns 1 and 2 are estimated with robust standard error to account for correlation due to intra-households clustering of preschool children in the survey data.

Table 3 also shows other correlates of household economic well-being. Education is positively associated with economic well-being and the magnitude and significance increase with higher levels of education. Permanent wealth (captured by log of land area) is highly statistically correlated with household economic well-being. The permanent wealth variable exhibits diminishing returns to scale on household economic well-being. Household size is inversely related to well-being, but the positive and significance of household size squared suggest that there is a critical size above which household size is positively related to economic well-being. Salaried workers in the private and public sectors contribute significantly in improving household economic well-being, whereas household members below 15 and above 60 years old do not contribute significantly in household well-being (Column 1 of Table 3). However, household members between 15 and 59 years old contribute very significantly to household economic well-being (Table 3 ). Female retirees ( $\geq 60$ years) correlate positively and somewhat significantly with household well-being, while their male counterparts register a negative correlation (Columns 2 and 3 of Table 3). This indicates that aged female heads are likely to be more productive than their male counterparts.

Is Child health then a necessary condition for income growth and poverty reduction?

As implied by Ajakaiye and Mwabu (2010), there is nothing automatic in the conversion of extra-time released because of better child health to improvements in household economic wellbeing and poverty reduction because it is contingent on a myriad of "if" clauses. Other things being equal, if wage and self-employment are available, improvements in child health could: (1) increase wage income and (2) raise profits from self-employment in farm and non-farm activities. Extra-time released because child is healthy may not engender household economic growth (higher incomes) if: (1) work is unavailable; (2) labour productivity is low; or (3) parents are unhealthy. If work is unavailable, improvements in child health would not enhance incomes and reduce poverty because the additional labour supply might instead depress wages or swell the existing unemployment. In addition, child health improvements may be short-lived if conditions do not exist for the population to create employment opportunities.

Thus, the necessary dynamic conditions linking improvements in reproductive health to economic growth and poverty reduction would include: (1) employment opportunities, (2) markets for labour intensive products, (3) equitable access to reproductive health services since once health is achieved, it is not redistributable. Above all, a favourable macroeconomic environment including a social protection system in which people can innovate and create wealth and employment opportunities when jobs do not exist is also a requirement.

\section{Concluding Remarks}

This paper has empirically estimated the response of household economic well-being to child health status and examined gender disparity in the response process, while controlling for other correlates. The 2001 Cameroon household survey initiated by the government's statistics office together with survey-based regressions in STATA were used to generate empirical results.

Empirical results showed that child health associates positively and significantly with the production of household economic well-being, surrogated by log of household total expenditures 
per adult. This is considered evidence of spill-over effects of child health on household economic well-being. The magnitude of the influence of better child health on production in female headed households was larger than that of their male counterparts. This was taken as indicating that when children are enjoying better health, female heads are likely to exploit the resulting extratime, budgetary savings and peace of mind at work to increase household well-being more effectively than their male counterparts. These results have implications for public interventions in the promotion of crèche/pre-nursery school centres as an important incentive for women to use extra-time at their disposal to participate additionally in labour market or training opportunities as a means of enhancing income growth and alleviating household poverty.

The down-side of female labour market participation is the propensity to unstable relationships and broken homes, if having to work entails migration. This highlights the need for relative equity considerations in the regional allocation of labour intensive projects that can absorb the extra-time released because of better child health. Thus a critical consideration is whether people can find work or self-employ themselves to absorb the extra-time released because of improvements in child health. It is also important that the goods produced use techniques that are intensive in skills possessed by the poor. By the same token, markets for labour intensive products are needed for poverty to decline.

Education was shown to be positively associated with economic well-being and the magnitude and significance increased with higher levels of education. Permanent wealth captured by log of land area was found to be significantly correlated with household economic well-being and exhibited diminishing returns to scale. Household size depicted a U-shaped effect on economic well-being and formal sector workers relate positively with economic well-being. Households in age groups 15-59 contributed significantly to household economic well-being.

These results suggest that investment in child health might, under favourable conditions, improve household incomes, reduce monetary poverty and enhance household capabilities, voice and participation in social, economic and political activities. This process might be more effective if access to financial services (micro-credit, micro-insurance) were improved. Investing in general health, especially child health and mother health can, given the right conditions, engender income growth, reduce poverty and initiate the process of accumulation of human capabilities. These may initiate the process of intergenerational transmission of socio-economic status.

For the benefit of further research, it is worthwhile to reiterate that this paper only captures contemporaneous effects of child health on household economic well-being. Typically, the effects of child health on productivity, cognition and other outcomes will have economic repercussions over the life-course. But these are more of long-term effects that cannot be adequately modelled from cross-sectional data on child health to say something about the subsequent impact on economic well-being. Moreover, if one has to take account of the healthproductivity linkage at the household level then one needs to take account of more than nutritional status; one needs to know the morbidity history of the child. By and large, however, weight-for-age is assumed to be subsuming both present and past morbidity. In addition, the separation of the benefits of health and education on well-being overlooks the complementarity between these two forms of human capital in impacting productivity and well-being. Further analysis on how allocation of time changes with better child health (or of monetary savings) may equally be value addition.

\section{References}

Ajakaiye, O. and Mwabu, G. 2010. Reproductive Health, Economic Growth and Poverty Reduction in Africa: A Framework, Paper presented during the AERC Side Event of the African Development Bank Annual Meetings, May 24, Abidjan, Côte d'Ivoire.

Arcand, Jean-Louis. 2001. Undernourishment and Economic Growth, in The State of Food and Agriculture 2001, Food and Agriculture Organization of The United Nations, Rome. 
Arora, S. 2001. Health Human Productivity and Long-Term Economic Growth. Journal of Economic History, Vol. 61(3) (Sept).

Barro, R. 1991. Economic Growth in a Cross Section of Countries. Quarterly Journal of Economics, Vol. 106 (2):407-443.

Barro, R. and Lee, J. 1994. Losers and Winners in Economic Growth, in Proceedings of the World Bank Annual Conference on Development Economics, 1993: Supplement to The World Bank Economic Review and The World Bank Research Observer. Bruno, Michael Pleskovic, Boris, eds., Washington, D.C., World Bank, pp. 267-297.

Barro, R. and Sala-I-Martin, X. 1995. Economic Growth, New York: McGraw- Hill.

Baye, F. M. and Fambon, S. 2009. Linking Parental Education, Child Health and Economic Well-being in Cameroon, Paper Presented at the Centre for the Study of African Economies (CSAE) Conference, at St Catherine's College, Oxford, 22-24 March, 2009.

Behrman, J.R. and Rosenzweig M. 2004. "Returns to Birthweight", Review of Economics and Statistics, 86 (2): 586-601.

Bhargava, A. 2001. Modeling the Effects of Health on Economic Growth, Journal of Health Economics, Vol. 20(3): 423-440.

Blackburn K, and Cipriani G. 1998. Endogenous fertility, mortality and growth, Journal of Population Economics, Vol. 11: 517-534.

Card, David. 2001. Estimating the Return to Schooling: Progress on Some Persistent Econometric Problems. Econometrica, Vol. 69(5): 1127-1160.

Bloom DE, Canning D, and Sevilla J. 2004. The effect of health on economic growth: a production function approach. World Development, Vol. 32:1-13.

Case, A. Fertig, A. and Paxson, C. 2005. The Lasting Impact of Childhood Health and Circumstance, Journal of Health Economics, Vol. 24: 365-389.

Dow, W. H. 1999. Flexible Discrete Choice Demand Models Consistent with Utility Maximization: An Application to Health Care Demand. American Journal of Agricultural Economics, Vol. 81(3): 680-685.

Dow, W. H., Philipson, T. J., and Sala-i-Martin, X. .99), Longevity Complementaries Under Competing Risks. American Economic Review, Vol. 89 (5): 1358-1371.

Easterly, W. and Levine, R. 1997. Africa's Growth Tragedy: Policies and Ethnic Divisions. Quarterly Journal of Economics, Vol. 112(4): 1203-1250.

Filmer, D, and Pritchett, L. 1999. The effect of household wealth on educational attainment: evidence from 35 countries. Population and Development Review, Vol. 25: 85-120.

Fogel, R. W. 1991. New Sources and New Techniques for the Study of Secular Trends in Nutritional Status, Health, Mortality, and the Process of Aging, National Bureau of Economic Research Working Paper Series on Historical Factors and Long Run Growth No. 26, May.

Fogel, R. W. 1994a. Economic Growth, Population Theory, and Physiology: The Bearing of Long-Term Processes on the Making of Economic Policy. American Economic Review, vol. 84 (3): 369-395.

Fogel, R. W. 1994b. The Relevance of Malthus for the Study of Mortality Today: Long Run Influences on Health, Morality, Labour Force Participation, and Population Growth, In Lindahl Kiessling, Kerstin; Landberg, Hans, eds. Population, economic development, and the environment, Oxford and New York: Oxford University Press, pp. 231-284.

Fogel, R. W. 2002. Nutrition, Physiological Capital, and Economic Growth, Pan American Health Organization and Inter-American Development Bank, available at http://www.paho.org/English/HDP/HDD/fogel.pdf

Fogel, R. W.; Wimmer, L. T. 1992. Early Indicators of Later Work Levels, Disease, and Death. National Bureau of Economic Research Working Paper Series on Historical Factors in Long Run Growth, No. 38, June.

Gallup, J. and Sachs, J. 2000. The Economic Burden of Malaria. Working Paper No. 52, Centre for International Development, Harvard University.

Garen, J. 1984. The Returns to Schooling: A Selectivity Bias Approach with a Continuous Choice Variable. Econometrica, Vol.52(5): 1199-1218. 
Gertler, P. and van der Gaag. 1990. Health Care Financing in Developing Countries, Johns Hopkins University Press, Baltimore

Gorstein, J., Sullivan, K. Yip R., de Onis, M. Trowbridge, F. Fajans, P. and Clugston G. 1994. Issues in the Assessment of Nutritional Status Using Anthropometry. Bulletin of the World Health Organization, Vol. 72: 273-283.

Grantham-McGregor S., Fernald L. and Sethuraman K. 1999. Effects of Health and Nutrition on Cognitive and Behavioural Development in Children in the First Three Years of Life. Part 1. Low Birth weight, Breastfeeding and Protein-energy Malnutrition. Food and Nutrition Bullettin, 20(1): 53-75.

Grossman M. 1972. On the concept of health capital and the demand for health. Journal of Political Economy, Vol. 80: 223-255.

Gupta I, and Mitra A. 2004. Economic growth, health and poverty: an exploratory study for India. Development Policy Review, Vol. 22: 193-206.

Handa, S. 1999. Maternal Education and Child Height. Economic Development and Cultural Change, Vol. 47(2): 421-439.

Haughton, D. and Haughton J. 1997. Explaining Child Nutrition in Vietnam. Economic Development and Cultural Change, Vol. 45(3): 541-556.

Jamison DT, Lau LJ, and Wang J. 2004. Health's contribution to economic growth in an environment of partially endogenous technical progress. Disease Control Priorities Project Working Paper No. 10, Fogarty International Center. Bethesda, MD.

Knowles, S. and Owen, P.F. 1995. Health capital and cross-country variations in income per capita in the Mankiew-Romer-Weil model. Economics Letter, Vol.48: 99-106.

Mayer-Foulkes, D. 2005. Human Development Traps and Economic Growth, In Guillem LópezCasasnovas, Berta Rivera and Luis Currais (eds), Health and Economic Growth: Findings and Policy, pp. 115-142, Mass. : MIT Press, Cambridge.

Mwabu, G. 2009. The Production of Child Health in Kenya: A Structural Model of Birth Weight. Journal of African Economies, Vol. 18(2): 212-260, Advance Access published July 22, 2008.

Preston SH. 1975. The changing relation between mortality and the level of economic development. Population Studies, Vol. 2: 231-248.

Ranis G, Stewart F, Ramirez A. 2000. Economic growth and human development. World Development, Vol. 28: 197-219.

Rosenzweig, Mark R., and Schultz, T. P. 1983. Estimating a Household Production Function: Heterogeneity, the Demand for Health Inputs, and Their Effects of Birth Weight.” Journal of Political Economy, Vol.91(50: 723-746.

Ruger J, Jamison D, Bloom D. 2001. Health and the economy. In: Merson M, Black R, Mills A, eds. International public health, diseases, programs, systems and policies, New York, Aspen Publishers.

Sachs, J. and Warner, A. 1995. Economic Reform and the Process of Global Integration," Brookings Papers on Economic Activity No. 1: 1-118.

Sachs, J. and Warner, A. 1997. Sources of Slow Growth in African Economies. Journal of African Economies, Vol. 6(3): 335-376.

Schürch, B. and Scrimshaw, N.S., eds. 1987: Effects of chronic energy deficiency on stature, work capacity and productivity, International Dietary Energy Consultancy Group, Lausanne.

Schultz, T.P. 1992. The Role of Education and Human Capital in Economic Development: An Empirical Assessment, Yale Economic Growth Centre Discussion Papers No. 670.

Schultz, T.P. 1997. Assessing the Productive Benefits of Nutrition and Health: An Integrated Human Capital Approach. Journal of Econometrics, Vol. 77(1): 141-158.

Schultz, T.P. 1999. Health and Schooling Investments in Africa. Journal of Economic Perspectives, Vol. 13(3): 67-88.

Statacorp. 2001. Stata Statistical Software, College Park Station, TX: Stata Corportation.

Steckel, R. 1995. Stature and the Standard of Living. Journal of Economic Literature, Vol. 33(4): 1903-1940. 
Strauss, J. 1990. Households, Communities, and Preschool Children's Nutrition Outcomes: Evidence from Rural Côte d'Ivoire. Economic Development and Cultural Change, Vol. 38(2): 231-261.

Strauss, J. and Thomas, D. 1998. Health, Nutrition, and Economic Development: Journal of Economic Literature, Vol. 36(2): 766-817.

Thomas, D.; Schoeni, R.F., and Strauss, J. 1997. Parental Investments in Schooling: Gender and Household Resource Allocation in Urban Brazil, RAND Labour and Population Program, Working Paper.

Waterlow, J. C., Buzina, R. Keller, W. Lane, J. M. Nichaman, M. Z. and Tanner, J. M. 1977. The Presentation and Use of Height and Weight Data for Comparing the Nutritional Status of Groups of Children Under the Age of 10 Years. Bulletin of the World Health Organization, Vol. 55(4): 489-498.

WHO Working Group. 1986. Use and Interpretation of Anthropometric Indicators of Nutritional Status", Bulletin of the World Health Organization, Vol. 64(6): 929-941.

Wilhelmson, Karl and Gerdtham, Ulf-G. 2006. Impact on economic growth of investing in maternal-newborn health, Issues in Maternal-Newborn Health and Poverty No. 3, World Health Organisation, Geneva, Switzerland

Wooldridge, J. M. 1997. On Two Stage Least Squares Estimation of the Average Treatment Effect in a Random Coefficient Model. Economics Letters, Vol. 56: 129-133.

Wooldridge, J. M. 2002. Econometric Analysis of Cross Section and Panel Data, MA: MIT Press, Cambridge.

Appendix:

Table A: Survey-based regressions of the Reduced-form estimates of Child health and Probit for Sample selection

\begin{tabular}{|c|c|c|}
\hline Variables & Child health & $\begin{array}{c}\text { Child health reported }=1 \text { and } 0 \\
\text { otherwise }\end{array}$ \\
\hline Primary education & $\begin{array}{l}0.062 \\
(0.35)\end{array}$ & $\begin{array}{l}-0.034 \\
(-0.68)\end{array}$ \\
\hline Secondary education & $\begin{array}{l}0.406^{*} \\
(1.85)\end{array}$ & $\begin{array}{c}-0.174^{* * *} \\
(-2.83)\end{array}$ \\
\hline University education & $\begin{array}{l}1.171^{\text {*** }} \\
(2.33)\end{array}$ & $\begin{array}{c}-0.392^{* * * *} \\
(-4.28)\end{array}$ \\
\hline logland & $\begin{array}{l}-0.246 \\
(-0.69)\end{array}$ & $\begin{array}{l}-0.135 \\
(-1.45)\end{array}$ \\
\hline logland sqaured & $\begin{array}{l}0.059 \\
(0.76)\end{array}$ & $\begin{array}{l}0.018 \\
(0.95)\end{array}$ \\
\hline Formal sector employment & $\begin{array}{l}0.018 \\
(0.11)\end{array}$ & $\begin{array}{l}0.194 \\
(2.58)\end{array}$ \\
\hline Household size & $\begin{array}{l}0.017 \\
(0.28)\end{array}$ & $\begin{array}{l}0.034^{*} \\
(1.88)\end{array}$ \\
\hline Household size squared & $\begin{array}{l}0.000 \\
(0.01)\end{array}$ & $\begin{array}{l}0.001 \\
(1.23)\end{array}$ \\
\hline 10-14 Years age group & $\begin{array}{l}-0.172^{* *} \\
(-2.04)\end{array}$ & $\begin{array}{l}0.016 \\
(0.63)\end{array}$ \\
\hline 15-19 Years age group & $\begin{array}{l}0.035 \\
(0.31)\end{array}$ & $\begin{array}{c}-0.102^{* * *} \\
(-5.93)\end{array}$ \\
\hline 20-24 Years age group & $\begin{array}{l}-0.028 \\
(-0.23)\end{array}$ & $\begin{array}{l}-0.023 \\
(-0.92)\end{array}$ \\
\hline 25-59 Years age group & $\begin{array}{l}-0.031 \\
(-0.26)\end{array}$ & $\begin{array}{l}-0.058^{* *} \\
(-2.47)\end{array}$ \\
\hline$\geq 60$ Years age group & $\begin{array}{c}0.375^{* * * *} \\
(2.85)\end{array}$ & $\begin{array}{c}0.051 \\
(1.2)\end{array}$ \\
\hline $\begin{array}{l}\text { Identification variables (aff } \\
\text { logdistfoodmkt }\end{array}$ & $\begin{array}{l}\text { lot log of hous } \\
-0.107^{* *}\end{array}$ & $\begin{array}{l}\text { xpenditures per adult) } \\
0.203^{* * * *}\end{array}$ \\
\hline
\end{tabular}


male_child

child_age

child_age squared

Rural

Constant

R-squared

F-Stat [df; p-value]

Partial R-squared (on excluded

instruments)

Test of Joint Significance of Identifying Variables / Anderson-Rubin test

F-stat

[df; p-value]

Underidentification tests (Anderson canon. corr. LR statistic)

Chi.sq

[df; p-value]

$407.98[5 ; 0.000]$

Sargan statistic (overidentification test of all instruments)

Chi-sq

[df; p-value]

Number of observations

Number of clusters [Design df]

Population

270.201 [4; 0.000$]$

4025

592 [586]

8614302
(7.62)

$0.055^{* *}$

(1.98)

$0.038^{* * *}$

(6.83)

$-0.001^{* * *}$

$(-6.07)$

$-0.271^{*}$

$(-3.04)$

$-0.069$

$(-0.26)$

$3[18,579 ; 0.000]$

Source: Computed by author using CHS II survey data and STATA 9.1.

Notes: (·) implies $t$-ratios. ${ }^{* * *}, * *$ and $*$ indicate $1 \%, 5 \%$ and $10 \%$ levels of significance, respectively.

4372

602 [596] 9357000 